International Journal of Current Advanced Research

ISSN: O: 2319-6475, ISSN: P: 2319 - 6505, Impact Factor: SJIF: 5.995

Available Online at www.journalijcar.org

Volume 6; Issue 3; May 2017; Page No. 3971-3974

DOI: http://dx.doi.org/10.24327/ijcar.2017.3974.0409

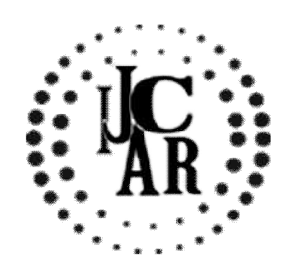

Research Article

\title{
ASSESSMENT OF VARIOUS TOOTHBRUSH GRIPS USED BY VISUALLY IMPAIRED CHILDREN FOR EFFECTIVE ORAL HYGIENE
}

\section{Shweta Chandak, Ankita Moon, Suryakant Kumar and Pali Dhongde}

Department of Pedodontics and Preventive Dentistry, SDKS Dental College and Hospital, Nagpur, Maharashtra, India;

\begin{tabular}{l}
\hline A R T I C L E I N F O \\
\hline Article History: \\
Received $20^{\text {th }}$ February, 2017 \\
Received in revised form $15^{\text {th }}$ March, 2017 \\
Accepted $4^{\text {th }}$ April, 2017 \\
Published online $28^{\text {th }}$ May, 2017
\end{tabular}

Key words:

Brushing grip, visually impaired children, oral hygiene.

\begin{abstract}
A B S T R A C T
Background: The most cited determinants of the effectiveness of toothbrushing in a child includes toothbrush design, brushing duration, parental involvement, brushing method, manipulative skill and manual dexterity. Aim: The aim of this study is to evaluate the tooth brushing ability and various toothbrush grips used in visually impaired children and its relation to oral hygiene. Materials and Methods: 100 visually impaired children including boys and girls aged 6 to 18 years from Dhyan Jyoti Nivasi Andha Vidhyalaya, Nagalwadi, Hingna, Nagpur were selected. On the basis of age group children were divided into three groups 6 to 10 years, 11-14 years, 15-18 years. Results: The most common grip used was power followed by distal oblique and the least common grip used was precision and visually impaired children have moderate to low grade of oral hygiene
\end{abstract}

Copyright $₫ 2017$ Shweta Chandak et al. This is an open access article distributed under the Creative Commons Attribution License, which permits unrestricted use, distribution, and reproduction in any medium, provided the original work is properly cited.

\section{INTRODUCTION}

Dental plaque is a biofilm that forms naturally on the surface of the teeth. ${ }^{1}$ It is one of the primary etiology for various oral diseases. Although the biofilm cannot be completely eliminated it can be controlled with comprehensive mechanical and oral hygiene practices. Routine tooth brushing is widely recognized as the initial step to alleviate the effects of dental plaque and maintain good oral health. ${ }^{2}$

Tooth-brushing methods and use of dentifrices play an important role in removing dental plaque and maintaining oral health. Other factors include duration of brushing, proper toothbrush grip, type of toothbrush used and duration for usage of toothbrush for effective oral hygiene. The most cited determinants of the effectiveness of toothbrushing in a child includes toothbrush design, brushing duration, parental involvement, brushing method, manipulative skill and manual dexterity. ${ }^{3}$

It is generally believed that tooth brushing is inefficient among children younger than 10 years, perhaps due to lack of motivation and poor manual dexterity, which is normal at this age. ${ }^{4}$

Beals et al. documented the interaction between the human hand and toothbrush during a toothbrushing session. They observed five grips, namely, the distal oblique and power grips, which use the palm of the hand, and the oblique, precision, and spoon grips, which rely on the fingers. ${ }^{5}$

\section{*Corresponding author: Shweta Chandak}

Department of Pedodontics and Preventive Dentistry, SDKS Dental College and Hospital, Nagpur, Maharashtra, India
Plaque removal depends not only on the type of brush or on the method of brushing but also on the individual having an effective technique (Saxer \& Yankell 1997). ${ }^{6}$

WHO defines blindness as having a 'visual acuity of less than $3 / 60 \mathrm{~m}$ or corresponding visual field loss in the better eye with the best possible correction' meaning that whilst a blind person could see $3 \mathrm{~m}$, a non visually impaired person could see $60 \mathrm{~m}$. Visual impairment relates to a person's eyesight which cannot be corrected to normal vision. ${ }^{7}$

This present cross sectional study was undertaken to determine the various toothbrush grips used by visually handicapping children and to evaluate its efficacy in maintaining oral hygiene.

\section{AIMS AND OBJECTIVES}

The aim of this study is to evaluate the tooth brushing ability and various toothbrush grips used in visually impaired children and its relation to oral hygiene for effective plaque control.

\section{MATERIALS AND METHODS}

100 visually impaired children including boys and girls aged 6 to 18 years who were cooperative and willing to participate were selected for the study from Dhyan Jyoti Nivasi Andha Vidhyalaya, Nagalwadi, Hingna, Nagpur. Clearance from local ethical committee, consent from the parents and Principal of the school participating in the study were obtained. Material used include Mouth mask and gloves and diagnostic Instrument like Mouth mirror, Probe and Explorer. The children were divided into three groups according to age: 
Group I- 6 to 10 years

Group II- 11-14 years

Group III- $15-18$ years

Children with medically compromised conditions, neuromuscular disorders, hearing impairment, and mental impairment were excluded.

\section{METHODOLOGY}

A questionnaire comprising of the demographic data like age and sex of the child and questions like whether tooth brushing is being monitored or not, duration of usage of a toothbrush by each child were recorded. The baseline OHI-S values of all the three groups were recorded. The children were then asked to brush. The type of toothbrush (soft, medium, hard), toothbrush grips (according to Beals et al) ${ }^{5}$ (fig. 1) duration of brushing and type of toothpaste used were recorded for each child individually without their knowledge.

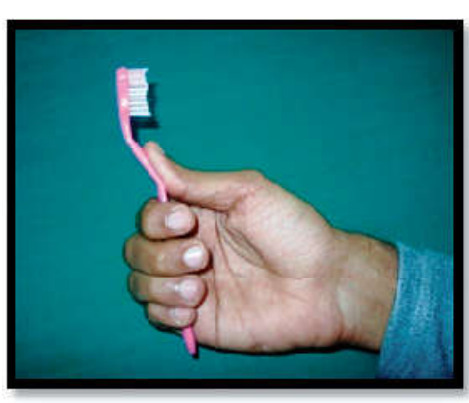

Distal oblique

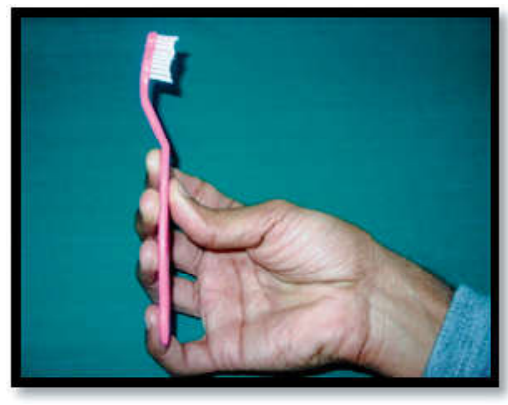

Oblique

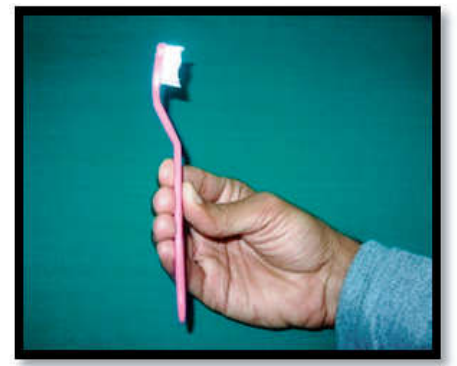

Precision

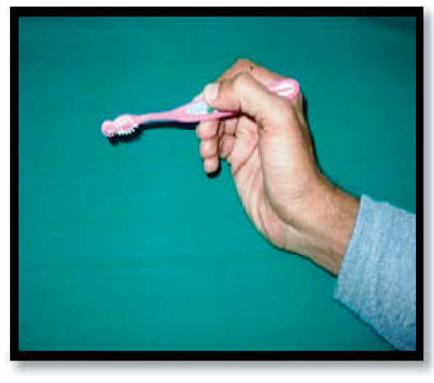

Spoon
Fig1 Toothbrush

\section{Statistical Analysis}

Statistical analysis was done by using descriptive and the analysis were SPSS 170 version and EPI-INFO 6.0 version and $p<0.05$ is considered as level of significance.

\section{OBSERVATIONS AND RESULTS}

Table 1 Age wise distribution of patients

\begin{tabular}{ccc}
\hline $\begin{array}{c}\text { Age } \\
\text { Group(yrs) }\end{array}$ & $\begin{array}{c}\text { No of } \\
\text { patients }\end{array}$ & Percentage $(\%)$ \\
\hline 6-10 years & 23 & 23 \\
11-14 years & 36 & 36 \\
15-18 years & 41 & 41 \\
Total & 100 & 100 \\
\hline
\end{tabular}

Table 2 Comparison of OHI-S Score in various age groups pre and post test

\begin{tabular}{cccc}
\hline Age Group (yrs) & $\begin{array}{c}\text { OHI-S before } \\
\text { brushing }\end{array}$ & $\begin{array}{c}\text { OHI-S after } \\
\text { brushing }\end{array}$ & t-value \\
\hline 6-10 yrs & $2.80 \pm 1.25$ & $2.74 \pm 1.23$ & $2.32 \mathrm{p}=0.030, \mathrm{~S}$ \\
$11-14$ yrs & $2.76 \pm 1.20$ & $2.66 \pm 1.13$ & $2.92 \mathrm{p}=0.006, \mathrm{~S}$ \\
$15-18$ yrs & $2.56 \pm 1.22$ & $2.42 \pm 1.19$ & $4.61 \mathrm{p}=0.0001, \mathrm{~S}$ \\
\hline
\end{tabular}
inferential statistics using Chi square test and software used in

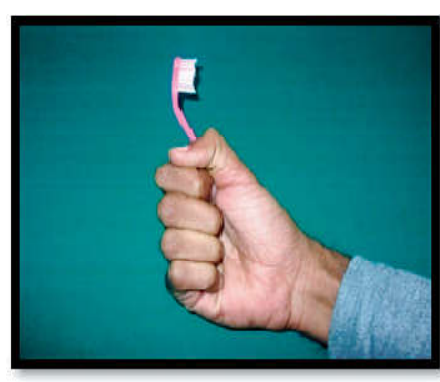

Power
Table 5 Agewise distribution of brushing grip

Table 3 Agewise distribution of type of tooth brush used

\begin{tabular}{ccccc}
\hline Age & \multicolumn{4}{c}{ Type of tooth brush used } \\
\cline { 2 - 5 } Group(yrs) & Hard & Medium & Soft & No Tooth Brush \\
\hline 6-10 years & 3 & 15 & 1 & 4 \\
11-14 years & 0 & 31 & 1 & 4 \\
15-18 years & 5 & 28 & 2 & 6 \\
Total & 8 & 74 & 4 & 14 \\
א2-value & \multicolumn{4}{c}{$6.28, \mathrm{p}=0.392, \mathrm{NS}, \mathrm{p}>0.05$} \\
\hline
\end{tabular}

Table 4 Agewise distribution of type of tooth paste used

\begin{tabular}{ccccc}
\hline Type of tooth & \multicolumn{4}{c}{ Age Group(yrs) } \\
\cline { 2 - 5 } paste used & $\mathbf{6 - 1 0}$ years & $\mathbf{1 1 - 1 4}$ years & $\mathbf{1 5 - 1 8}$ years & Total \\
\hline Fluoridated & 19 & 33 & 36 & 88 \\
Non-fluoridated & 2 & 3 & 5 & 10 \\
No Tooth Paste & 2 & 0 & 0 & 2 \\
Total & 23 & 36 & 41 & 100 \\
N2-value & \multicolumn{4}{c}{$16.95, \mathrm{p}=0.151, \mathrm{NS}, \mathrm{p}>0.05$} \\
\hline
\end{tabular}

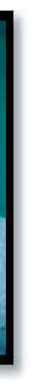

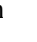

\begin{tabular}{cccc}
\multicolumn{4}{c}{ Age Group(yrs) } \\
\hline 6-10 years & 11-14 years & $\mathbf{1 5 - 1 8}$ years & Total \\
\hline 7 & 9 & 9 & 25 \\
4 & 6 & 6 & 16 \\
5 & 12 & 13 & 30 \\
1 & 1 & 1 & 3 \\
2 & 4 & 6 & 12 \\
19 & 32 & 35 & 86 \\
& $1.843, \mathrm{p}=0.985, \mathrm{NS}, \mathrm{p}>0.05$ &
\end{tabular}

Table 6 Agewise distribution of brushing technique

\begin{tabular}{ccccc}
\hline Brushing & \multicolumn{4}{c}{ Age Group $(\mathbf{y r s})$} \\
\cline { 2 - 5 } Technique & $\mathbf{6 - 1 0}$ years & $\mathbf{1 1 - 1 4}$ years & $\mathbf{1 5 - 1 8}$ years & Total \\
\hline Horiontal Scrub & 19 & 32 & 35 & 86 \\
Total & 19 & 32 & 35 & 86 \\
\hline
\end{tabular}

Table 7 Agewise distribution of duration of brushing

\begin{tabular}{ccccc}
\hline \multirow{2}{*}{ Duration of brushing } & \multicolumn{4}{c}{ Age Group(yrs) } \\
\cline { 2 - 5 } & 6-10 years & $\mathbf{1 1 - 1 4}$ years & $\mathbf{1 5 - 1 8}$ years & Total \\
\hline $15-30$ seconds & 8 & 5 & 12 & 25 \\
$30-60$ seconds & 6 & 17 & 13 & 36 \\
$\geq 1$ min & 9 & 14 & 16 & 39 \\
Total & 23 & 36 & 41 & 100 \\
א2-value & \multicolumn{5}{c}{$5.05, \mathrm{p}=0.282, \mathrm{NS}, \mathrm{p}>0.05$} \\
\hline
\end{tabular}


Table 8 Agewise distribution of duration of usage of toothbrush

\begin{tabular}{ccccc}
\hline \multirow{2}{*}{$\begin{array}{c}\text { Usage of } \\
\text { toothbrush }\end{array}$} & $\begin{array}{c}\text { 6-10 } \\
\text { years }\end{array}$ & $\begin{array}{c}\mathbf{1 1 - 1 4} \\
\text { years }\end{array}$ & $\begin{array}{c}\mathbf{1 5 - 1 8} \\
\text { years }\end{array}$ & Total \\
\hline$<3$ month & 8 & 5 & 12 & 25 \\
$=3$ month & 6 & 17 & 13 & 36 \\
$\geq 4$ month & 9 & 14 & 16 & 39 \\
Total & 23 & 36 & 41 & 100 \\
×2-value & \multicolumn{5}{c}{$5.05, \mathrm{p}=0.282, \mathrm{NS}, \mathrm{p}>0.05$} \\
\hline
\end{tabular}

Table 9 Agewise distribution of frequency of brushing

\begin{tabular}{ccccc}
\hline \multirow{2}{*}{$\begin{array}{c}\text { Frequency of } \\
\text { brushing }\end{array}$} & $\begin{array}{c}\text { 6-10 } \\
\text { years }\end{array}$ & $\begin{array}{c}\text { Age Group(yrs) } \\
\text { years }\end{array}$ & $\begin{array}{c}\mathbf{1 5}-18 \\
\text { years }\end{array}$ & Total \\
\hline Once a day & 23 & 36 & 39 & 98 \\
Twice a day & 0 & 0 & 2 & 2 \\
Total & 23 & 36 & 41 & 100 \\
\&2-value & \multicolumn{4}{c}{$2.93, \mathrm{p}=0.230, \mathrm{NS}, \mathrm{p}>0.05$} \\
\hline
\end{tabular}

Table 10 Agewise distribution of monitoring by

\begin{tabular}{ccccc}
\hline \multirow{2}{*}{ Monitoring by } & \multicolumn{4}{c}{ Age Group $(\mathbf{y r s})$} \\
\cline { 2 - 5 } & $\mathbf{6 - 1 0}$ years & $\mathbf{1 1 - 1 4}$ years & $\mathbf{1 5 - 1 8}$ years & Total \\
\hline Self & 22 & 36 & 41 & 99 \\
Parents & 1 & 0 & 0 & 1 \\
Total & 23 & 36 & 41 & 100 \\
א2-value & & $3.38, \mathrm{p}=0.184, \mathrm{NS}, \mathrm{p}>0.05$ & \\
\hline
\end{tabular}

\section{RESULTS}

There was significance difference (Age- 6-10 years $p=0.0001$, Age 11-14 years $p=0.006$, Age $15-18$ years $p=0.030$ ) between grips and OHI-S before and after brushing in all the age groups (Table 2). Children were found to use both toothbrush and finger (Table 3). Fluoridated toothpaste was most commonly used compared to non-fluoridated toothpaste (Table 4). Among all the age groups, the most common grip used was power followed by distal oblique and the least common grip used was precision (Table 5). There was no relation between the age of children and toothbrush grips (Table 5). The most common technique of brushing was found to be Horizontal scrub method (Table 6). There was no significance in the age group and duration of brushing (Table 7). Among 100 children 39 children use his/her toothbrush for more than 4 months (Table 8). Children were found to brush once a day without any monitoring and guidance on their own (Table 9 \&10).

\section{DISCUSSION}

In the present study, 100 visually impaired children were selected and were divided into 3 groups based on age. This was done to compare and correlate oral hygiene among these groups. Tooth brushing varies among children based on their dexterity, physical and neurological development. The oral hygiene had found to be fair to poor. Fluoridated toothpaste was routinely used by the children in all the age groups and it was observed that two children never used a toothbrush/toothpaste/toothpowder for oral hygiene maintenance. Hence, the lack of awareness regarding the oral hygiene maintenance was observed in this group of children. Some studies (Radentz et al. 1976, Sangnes \& Gjermo 1976) indicate that traumatization of soft or hard tissue is not related to the brushing method. ${ }^{8,9}$ Frandsen 1985 stated that the efficacy of brushing with regard to plaque removal is dictated by three main factors: the design of the brush, the skill of the individual using the brush and the frequency and duration of use. $^{5}$ The present study shows maximum usage medium grade bristle brush and horizontal scrub method being most common technique used. Frequency of brushing was found to be once a day.

In the present study, there was no significance found in time taken for brushing, Vander Weijden et al. study (1993) stated that the best estimate of actual manual brushing time seems to range between 30 and 60 second. ${ }^{10}$

The impact of grip on tooth brushing cannot be underestimated as majority of children used power followed by distal oblique grips. The ability of children to manipulate toothbrushes in the oral cavity varies according to their dexterity at different stages of their physical and neurological development. It is logical to assume that the more efficient the brushing technique, the better the effectiveness of plaque removal from the various surfaces of the teeth.

Tooth brushing is not like painting or scrubbing a wall, as it requires manipulation of the brush around different surfaces of the teeth and in various inaccessible areas, which might not be possible for a younger child. Considerable effort has been made in understanding the relationship between grips and technique. ${ }^{11,12,13}$

\section{CONCLUSION}

After conducting a survey and analyzing the results, it can be concluded that visually impaired children have moderate to low grade of oral hygiene. Power and distal oblique grip were more commonly used by visually impaired children. Oral hygiene awareness and maintenance of oral hygiene should be incorporated in such children. Such children need education and motivation about oral health.

\section{References}

1. Marsh PD, Bradshaw DJ, Dental plaque as a biofilm. Journal of Industrial Microbiology 1995; 15: 169-175.

2. Axelsson P. Mechanical plaque control In: Lang NP, Karing Teds, Procedings of the $1^{\text {st }}$ European workshop on periodontology. Chicago, Quintessance, 1993; 1:219-43.

3. Sarika Sharma, Ramakrishna Yeluri, Amit A. Jain and Autar K. Munshi. Effect of toothbrush grip on plaque removal during manual toothbrushing in children. Journal of Oral Science, 2012; 54(2): 183-190.

4. Grossman E, Proskin H (1997) A comparison of the efficacy and safety of an electric and a manual children's toothbrush. J Am Dent Assoc 128,469-474.

5. Beals D, Wong-Paredes M, Allen B, Rutter B, Stegemen J (1999) Grip architecture in manual toothbrushing. J Dent Res 78, Spec, 413. (abstract)

6. Saxer, U. P. \& Yankell, S. L. (1997) Impact of improved toothbrushes on dental diseases. Quintessence International 28, 573-593.

7. Solanki J, Gupta S, Chand S; Comparison of dental caries and oral hygiene status among blind school children and normal children, Jodhpur city Rajasthan, India. Universal Research Journal of Dentistry, 2014; 4(1): 22-25.

8. Radentz, W. H., Barnes, G. P. \& Cutright, D. E. (1976) A survey of factors possibly associated with cervical abrasion of tooth surfaces. Journal of Periodontoiogy 47, 148-154. 
9. Sangnes, G. \& Gjermo, P (1976) Prevalence of oral soft and hard tissue lesions related to mechanical toothcleansing procedures. Community Dentistry and Orai Epidemiology 4, 77-83.

10. Practice, pp. 3-119. Oxford: IRL Press Ltd.

11. Morris, A. J., Steele, J. \& White, D. A. (2001) The oral cleanliness and periodontal health of UK adults in 1998. British Dental Journal 191, 186-192.
12. Mentes A, Atukeren J (2002) A study of manual toothbrushing skills in children aged 3 to 11 years. $J$ Clin Pediatr Dent 27, 91-94.

13. Das UM, Singhal P (2009) Tooth brushing skills for the children aged 3-11 years. J Indian Soc Pedod Prev Dent 27, 104-107.

\section{How to cite this article:}

Shweta Chandak et al (2017) ' Assessment Of Various Toothbrush Grips Used By Visually Impaired Children For Effective Oral Hygiene', International Journal of Current Advanced Research, 06(05), pp. 3971-3974.

DOI: http://dx.doi.org/10.24327/ijcar.2017.3974.0409 